\title{
“Nose Job": Possible Side Effects of Sars-Cov-2
}

\author{
Robert King ${ }^{1}$
}

Received: 28 June 2021 / Revised: 16 January 2022 / Accepted: 17 January 2022 / Published online: 7 February 2022

(c) The Author(s), under exclusive licence to Springer Science+Business Media, LLC, part of Springer Nature 2022

\section{Introduction}

One of the much-reported effects of SARS-Cov-2, including the effects of so-called long covid, is a change in smell perception, although the underlying causal mechanism is unclear (Brann et al., 2020). The effects of anosmia may be more profound than people appear to be considering, and, furthermore, have sexual implications.

As Jennifer Anniston is reported to have said, "The best smell in the world is that man that you love." True as that is, the effect of partner smell goes beyond mere pleasure, and anyone with even a passing knowledge of how evolution works, knows that nature does not hand out free lunches.

We know that changes in smell perception, attendant on use of the contraceptive pill can drastically change women's attraction to their partners (Alvergne \& Lummaa, 2010). We have also found that attractive partner smell is a key determinant of sexual response and orgasm intensity (King \& Belsky, 2012). While it is disputed exactly what is being signaled by partner smell, it is not in dispute that smell matters, especially to women, whose extra sensitivity to smell (Allen et al., 2016) and 40\% (!) extra density of olfactory neural tissue is, presumably, doing something important (Oliveira-Pinto et al., 2014).
It is therefore likely that the effects of covid are going to be seen by sex therapists, marriage guidance counselors, and similar, in the months and years to come.

\section{References}

Allen, C., Cobey, K. D., Havlíček, J., \& Roberts, S. C. (2016). The impact of artificial fragrances on the assessment of mate quality cues in body odor. Evolution and Human Behavior, 37(6), 481-489.

Alvergne, A., \& Lummaa, V. (2010). Does the contraceptive pill alter mate choice in humans? Trends in Ecology \& Evolution, 25(3), 171-179.

Brann, D. H., Tsukahara, T., Weinreb, C., Lipovsek, M., Van den Berge, K., Gong, B., ... Datta, S. R. (2020). Non-neuronal expression of SARS-CoV-2 entry genes in the olfactory system suggests mechanisms underlying COVID-19-associated anosmia. Science Advances, 6(31), 5801.

King, R., \& Belsky, J. (2012). A typological approach to testing the evolutionary functions of human female orgasm. Archives of Sexual Behavior, 41(5), 1145-1160.

Oliveira-Pinto, A. V., Santos, R. M., Coutinho, R. A., Oliveira, L. M., Santos, G. B., Alho, A. T., ... Pasqualucci, C. A. (2014). Sexual dimorphism in the human olfactory bulb: females have more neurons and glial cells than males. PloS ONE, 5(11), e111733.

Publisher's Note Springer Nature remains neutral with regard to jurisdictional claims in published maps and institutional affiliations.
Robert King

r.king@ucc.ie

1 School of Applied Psychology, University College Cork, Cork T12 K8AF, Ireland 